\title{
PELANGGARAN KODE ETIK ADVOKAT DALAM PEMBUATAN SURAT KUASA
}

\author{
Sari Aprilianti \\ Fakultas Hukum, Universitas Kuningan, Indonesia \\ Email : s.aprilianti@yahoo.com
}

\begin{abstract}
The purpose of this study is to find out how the form of accountability of an advocate for violations of the code of ethics in the power of attorney. The research method used is normative juridical, which is an approach method by studying the law which is conceptualized as a norm or rule that applies in society, and serves as a reference for everyone's behavior. data collection tool through library research. ata used secondary, that is data obtained through the study of documentation by reading scientific books, magazines, internet, newspapers and other readings related to research. The results of the study are violations given to Advocates not only refer to Law No. 18 of 2003 but are regulated in the Advocate Code of Ethics where in article 16 (1) the Advocate Code of Ethics given by the Organization to Advocates is almost the same as article 7 paragraph (1) Law No. 18 of 2003 which in article 16 paragraph (1) of the Advocate Code of Ethics states that "(1) Punishment given in a decision can be in the form of: Ordinary warning; Loud warning; Temporary stop for a certain time; and dismissal from membership of professional organizations.
\end{abstract}

Keywords: sanctions; code of Ethics; ethics; advocate.

\section{Abstrak}

Tujuan penelitian ini adalah untuk mengetahui bagaimana bentuk pertanggung jawaban seorang advokat terhadap pelanggaran kode etik dalam pembuatan surat kuasa. Metode penelitian yang digunakan adalah yuridis normatif, yaitu metode pendekatan dengan mengkaji hukum yang dikonsepkan sebagai norma atau kaidah yang berlaku dalam masyarakat, dan menjadi acuan perilaku setiap orang. alat pengumpul data melalui studi kepustakaan. ata yang digunakan sekunder, yaitu data yang diperoleh melalui studi dokumentasi dengan cara membaca buku-buku ilmiah, majalah, internet, surat kabar dan bacaan-bacaan lain yang berhubungan dengan penelitian. Hasil penelitian yaitu pelanggaran yang diberikan kepada Advokat tidak hanya mengacu pada UU no 18 tahun 2003 akan tetapi diatur pada Kode Etik Advokat yang dimana pada pasal 16 (1) Kode Etik Advokat yang diberikan oleh Organisasi kepada Advokat hampir sama dengan pasal 7 ayat (1) UU no 18 tahun 2003 yang dimana pada pasal 16 ayat (1) Kode Etik Advokat menyebutkan bahwa "(1) Hukuman yang diberikan dalam keputusan dapat berupa: Peringatan biasa; Peringatan keras; Pemberhentian sementara untuk waktu tertentu; dan Pemecatan dari keanggotaan Organisasi profesi.

Kata Kunci : sanksi; kode etik; etika; advokat.

\section{PENDAHULUAN}

Dalam kehidupan manusia diuji dengan cobaan dan hukuman, jika manusia itu dalam suatu permasalahan suatu tindak pidana atau perdata maka seseorang dapat membutuhkan seseorang untuk membantu yaitu seseorang ahli yang berhubungan dengan hukum atau orang yang bekerja di bidang jasa yaitu penasihat hukum atau advokat karena setiap warga negara berhak mendapatkan pendampingan dalam ranah hukum karena hak seseorang untuk mendapatkan suatu pendampingan hukum tersebut itu sudah tertulis. Disamping itu advokasi berupaya menyadarkan hak-hak masyarakat sebagai subyek hukum yang memiliki sejumlah hak dan kewajiban yang dijamin oleh konstitusi dan berbagai peraturan, menegakkan perlindungan hukum sebagai bagian dari upaya menegakkan prinsip negara hukum, membantu penyelesaian permasalahan hukum yang dihadapi oleh masyarakat dengan cara pendampingan hukum atau yang dimaksudkan dengan jasa hukum. Permasalahan pidana dalam masyarakat tidak terselasaiakan akibat ketidaktahuan terhadap 
proses peradilan pidana, disamping itu masyarakat biasanya acuh dengan permasalahan hukum dan enggan mengunakan jasa advokat karena mengangap jasa advokat itu mahal. Anggapan bahwa kasus pidana tidak banyak memberikan keuntungan bagi pengacara turut menimbulkan komersialisasi hukum bagi masyarakat miskin yang terkena permasalahan pidana.

Undang-Undang Dasar 1945 Pasal 27 ayat (1) secara jelas dan tegas menjamin adanya persamaan di depan hukum (equality before the law) dan pasal 28D ayat 1 bahwa setiap orang berhak mendapatkan pengakuan, jaminan, perlindungan, dan kepastian hukum yang seadil-adilnya serta di perlakukan sama di hadapan hukum. Disamping itu salah satu hak dasar warga negara dalam bidang hukum ialah mendapatkan pendampingan advokat. Bantuan hukum adalah hak dari orang miskin yang dapat diperoleh tanpa bayar (pro bono publico) sebagai penjabaran persamaan hak di hadapan hukum.

Bantuan hukum adalah jasa atau profesi hukum untuk membantu setiap individu untuk memperoleh keadilan, memperoleh hak asasi dalam harkat dan martabatnya sesuai dengan prinsip semua orang memiliki hak dan martabat. Pemberi bantuan hukum diidentikkan dengan "Orator" yang dalam tindakan diakui sebagai golongan yang memiliki pengetahuan luas di bidang hukum, berpendidikan dan berjuang untuk membela sesuatu yang hak di depan hukum dan kekuasaan bagi masyarakat pencari keadilan yaitu orangorang yang lemah dan miskin di depan hukum dan pengadilan'.

Hal ini sesuai dengan ketentuan Pasal 34 ayat (1) UUD 1945 ditegaskan bahwa fakir miskin adalah menjadi tanggung jawab negara.Terlebih lagi prinsip persamaan di hadapan hukum (equality before the law) dan hak untuk di bela Advokat (access to legal counsel) adalah hak asasi manusia yang perlu dijamin dalam rangka tercapainya pengentasan masyarakat Indonesia dari kemiskinan, khususnya dalam bidang hukum.

Dengan adanya metode yang lebih tersruktur pada sistem peradilan pidana diharapkan pemberian bantuan hukum dapat dilaksanakan secara ilmiah dan sistematis sehingga hasil yang diharapkan mewujudkan hak-hak tersangka atau terdakwa bagi penegakan keadilan dapat tercapai kearah yang lebih baik. Relevansi bantuan hukum dalam kegiatan advokasi dalam perkara pidana bahwa metode advokasi dapat dimanfaatkan untuk mempercepat proses penanganan kasus-kasus hukum pidana bagi masyarakat yang kurang mampu, terutama pada kasus yang kurang mendapat perhatian serius.

Sehingga terkatung-katung atau tidak segera mendapat penyelesaian. Karena terkadang sbeagian kecil seorang advokat mementingkan klien besar atau orang yang mempunyai uang banyak dan terjadi adanya pelanggaranpelanggaran pembuatan surat kuasa yang dimana klien atau seorang tersangka diombang ambing sehingga terjadinya pelanggaran tentang pembuatan surat kuasa yang mengakibatkan kerugian yang dialami oleh seorang klien dan pada jaman sekarang etika sedang menurun yang menyebabkan seseoarang menghalalkan segala cara untuk memperoleh sesuatu yang diinginkan yang mengakibatkan pelanggaran-pelanggaran kode etik. Jika dilihat seseorang advokat harus mempunyai etika profesi dan setiap advokat dalam menjalankan tugasnya sesuai dengan

\footnotetext{
${ }^{1}$ Habiburrahman (Hakim Agung RI) disampaikan dalam makalah seminar nasional "Mediasi dan Bantuan Hukum di Lingkungan Peradilan Agama; Agenda dan Problematika" diselenggarakan oleh program studi Hukum Islam dan Program Pascasarjana fakultas ilmu agama UII bekerjasama dengan MA RI.
} 
kode etik advokat agar setiap adovokat tidak saling sikut antar advokat lain yang dapat membuat persetruan antar advokat. Setiap advokat harus mempunyai etika dalam bekerja. Berdasarkan uraian latar belakang di atas, penulis tertarik mengkaji lebih jauh tentang Bagaimanakah bentuk pertanggung jawaban seorang advokat terhadap pelanggaran kode etik dalam pembuatan surat kuasa?

\section{METODE PENELITIAN}

Metode penelitian yang digunakan oleh penulis adalah Yuridis Normatif, dengan alat pengumpul data melalui studi kepustakaan yaitu studi dokumentasi peraturan perundangundangan serta artikel-artikel yang terkait dengan penelitian ini.

\section{HASIL DAN PEMBAHASAN}

\section{A. Pengertian Etika}

Etika ketika setiap manusia dalam pergaulan agar tidak terjadi ketersinggungan dan pandangan sosial yang buruk setiap manusia dalam bergaul harus mempunyai tatakrama atau yang sering di sebut dengan etika dan etika membuat seseorang dapat menentukan bagaimana bergaul dan hidup bermasyarakat. Etika merupakan berasal dari bahasa Yunani kuno yaitu ethos dalam bentuk tunggal memepunyai banyak arti dari tempat tinggal yang biasa, padang rumput, kandang, kebiasaan, adat, akhlak, watak, perasaan sikap cara berfikir dan dalam bentuk jamak (ta etha) adalah adat kebiasaan².

Dalam kamus besar Bahasa Indonesia etika (1) ilmu pengatahuan tentang moral. (2) peraturan tentang kelakuan yang benar dan yang salah. (3) buku tentang etika ${ }^{3}$. Dan bisa di ambil kesimpulan bahwa etika merupakan ilmu pengetahuan tentang moral dan merupakan adat kebiasaan untuk mengetahui tentang kelakuan baik atau buruk manusia atau etika dapat diartikan sebagai kumpulan asas atau nilai moral, filsafat moral, dan yang terpenting sebagai nilai-nilai dan norma-norma moral yang menjadi pegangan manusia atau kelompok manusia dalam mengatur perilakunya.

Nilai dan norma moral tersebut merupakan kebiasaan yang menggambarkan perangai manusia dalam hidup bermasyarakat, dan perilaku baik-buruk, benar dan salah berdasarkan kodrat manusia yang diwujudkan melalui kebebasan kehendak. Dalam berkahendak setiap individu seharusnya mengerti keadaan yang dimana dalam sebuah lingkungan setiap individu hidup dalam kehidupan bermasyarakat. Menurut para pakar etika dijelaskan sebagai berikut:

Menurut james J. Spellane SJ mengungkapkan bahwa etika atau ethics memperhatikan atau memepetimbangkan tingkah laku manusia dalam pengambilankeputusan moral. Etika mengarahkan atau menghubungkan penggunaan akal budi individual dengan objeksivitas untuk menentukan "kebenaran" atau "kesalahan" dan tingkah laku seseorang terhadap orang lain.

Menurut suhardi K Lubis dalam istilah latin, ethos atau ethikos selalu disebut dengan mos, sehingga dari perkataan tersebut lahirlah moralitas atau yang sering

\footnotetext{
${ }^{2}$ Bertens K. Etika. PT. gramedia Pustaka Utama. Jakarta. 2002. Hal 4

${ }^{3}$ Peter Salim. Kamus Besar Bahasa Indonesia Kontemporer.Modern Englishpres. Jakarta. Edisi pertama 1991. etika hal 409
} 
diistilahkan dengan perkaat moral, namun demikian apa bila dibandingkan dalam pemakaian yang lebih luas perkataan etika lebih di pandang sebagai lebih luas dari perkataan moral, sebab terkadang istilah moral sering digunakan hanya untuk menenrangkan seikap lahiriah seseorang yang biasa dinilai dari wujud tingkah laku atau perbuatan nyata ${ }^{4}$. Menurut A sonny keraf etika dipahami dalam pengertian moralitas sehinggamemepunyai pengertian yang jauh lebih lebih luas. Etika dimenegerti sebagai refleksi kritis tetang bagaimana manusia harus hidup dan bertindak dalam sistem situasi konkret, situasi khusus tertentu.Etika adalah filsafat moral atau ilmu yang membahas dan mengkaji secara kritis persoalan benar dan salah, tentang bagimana harus bertindak dalam situasi konkret 5 .

\section{B. Pengertian Moral}

Moral menurut kamus bahasa Indonesia adalah ajaran atau pendidikan mengenai baik buruknya perbuatan, sikap, kewajiban dan sebagainya dalam arti lain morala merupakn keadaan atau kondisi mental yang membuat orang tetap berani, bersemangat, bergairah dan sebagainya ${ }^{6}$.

Moral dapat dikatakan sebagai cermin dari kehidupan individu manusia karena setiap manusia mempunyai moral yang berbeda dan perbedaan moral setiap individu manusia tersebut dinilai oleh individu yang lain sehingga penilaian tentang individu dengan individu yang lain diliahat dari moral karena moral merupakan awal dari semua kehidupan bermasyarakat. Etika dan moral sangatlah berkaitan erat karena dalam kehidupan bermasyarakat moral dan etika dibutuhkan tanpa etika dan moral tanpa etika dan moral individu tersebut seperti individu yang hidup sebelum peradapan yang tidak mengerti apa itu moral dan etika karena itu dalam suatu pekerjaan juga perlu adanya moral dan etika profesi. Merurut Kadir Muhammad, mengatakan bahwa kata yang sangat dekat dengan "etika" adalah moral. Kata ini berasal dari bahasa latin "mos" jamaknya "mores" yang juga berarti adat kebiasaan. Secar etimologis, kata etika sama dengan kata moral, keduanya berates adat kebiasaan. Perbedaanya hanya pada bahasa asalnya, etika berasal dari bahasa yunan sedangkan moral berasal dari bahasa lain ${ }^{7}$.

Orang yang memiliki moral berarti mempunyai moralitas yang baik, moralitas merupakan suatu perbuatan, tingkah laku manusia yang berhubungan dengan sopan santun yang berkenaan dengan moral makamoral sangatlah penting bagi kehidupan manusia yang dimana sebagai pondasi dalam kehidupan sehari-hari.

\section{Etika Profesi}

Setiap pekerjaan merupakan salah satu keinginan setiap manusia untuk memenuhi kehidupan dan menyaluarkan keahlian manusia dalam dunia pendidikan yang ditempuhnya akan tetapi setiap bidang pekerajaan ada etika dalam profesi karena etika profesi merupakan

\footnotetext{
${ }^{4}$ Sutrisno. Etika Profesi Hukum. upnprees. Surabaya. 2011. hal 5

${ }^{5}$ Ibid hal 6

${ }^{6}$ Salim Peter. Kamus Besar Bahasa Indonesia Kontemporer.Modern Englishpres. Jakarta. edisi pertama 1991. moral hal 1995

${ }^{7}$ Yulianingsih, wiwin. Etika Profesi Hukum. upnpress. Surabaya. 2011. hal 7
} 
salah satu alur dalam suatu bidang pekerjaan dan pembatasan apa dan bagaimana suatu bidang pekerjaan itu berjalan tanpa melanggar aturanaturang yang sudah ada dan bila terjadi adanya penyimpangan etika profesi maka manusia tersebut akan disorot oleh atasan dan masyarakat.

Etika dikaitkan dengan profesi yang merupakan suatu pekerjaan dengan keahlian khusus, menuntut pengetahuan dan tanggung jawab, diabadikan untuk kepentingan orang banyak, mempunyai organisasi profesi dan mendapat pengakuan dari masyarakat, serta kode etik, maka etika merupakan alat untuk mengendalikan anggota masingmasing profesi. Secara leih tegas dapat dikatakan bahwa peran etika, dalam profesi sebagai alat pengendalian hati nurani atau kodeetik atau tidak.Oleh karena itu disini merupakan pencerminan ilmiah dalam perilaku manusia dari sudut norma-norma baik maupun buruk ${ }^{8}$.

\section{Pengertian Profesi}

Pengertian profesi ialah suatu bidang pekerjaan yang berdasarkan keahlian tertentu atau ruang lingkup yang berdeda yang terdiri dari beberapa ahli yang merupakan difinisi beraneka ragam. Profesi menurut para pakar, menurut komarudin dalam ensiklopedi manajemen menjelaskan bahwa profesi (profession) ialah suatu jenis pkerjaan yang karena sifatnya menuntut pengetahuan yang tinggi, khusus dan latihan yang istimewa ${ }^{9}$.

Menurut frans magbis suseno (1991:70), profesi itu harus dibedakan dua jenis yaitu profesi pada umumnya dan profesi luhur. Pada umumnya, paling tidak ada dua prinsip yang wajib di tegakkan yaitu:

1. Prinsip agar menjalankan profesinya secara sertangggung jawab dan

2. Hormat terhadap hak oranglain.

Pengertian serta tanggung jawab ini menyangkut, baik terhadap pekerjaannya maupun hasilnya, dalam arti yang bersangkutan harus menjalankan pekerjaannya dengan sebaik mungkin dengan hasil yang berkualitas. Selain itu, juga di tuntut agar dampak pekerjaan yang dilakukan tidak sampai merusak lingkungan hidup, artinya menghormati hak orang lain.

Dalam profesi yang luhur (officium nobile), motivasi utama bukan untuk memeperoleh nafkah dari pekerjaan yang dilakukan, di samping itu juga terdapat dua prinsip yang penting, yaitu:

1. Mendahulukan kepentingan orang yang dibantu.

2. Mengabdi pada tuntutan luhur profesi ${ }^{10}$.

Untuk melaksanakan profesi luhur secara baik, dituntut moralitas yang tinggi dari pelakunya. Tiga ciri moralitas yang tinggi adalah:

1. Berani berbuat dengan bertekad untuk sesuai dengan tuntutan profesi.

2. Sadar akan kewajibannya.

3. Memiliki idealism yang tinggi"

\footnotetext{
${ }^{8}$ Ibid hal 26

${ }^{9}$ Sutrisno. Etika Profesi Hukum. upnpress. Surabaya. 2011. hal 14

${ }^{10}$ Ibid. hal 15

${ }^{11}$ Ibid. hal 15
} 
Maka setiap profesi seseorang setidaknya dan tidaklah lain adalah dengan atau dengan sesuai keahlian masing-masing dengan kata lain suatu pekerjaan setidaknya sesuai dengan bidangnya agar tidak adanya rasa menyesal apabila melakukan suatu pekerjaan yang bukan bidangnya walaupun terkadang sauatu yang baru dalam bidang suatu pekerjaan yang bukan bidangnya maka bias di bilang tantangan baru akan tetapi semua itu merupakan harus adanya pembelajaran yang dimulai dari awal sehingga bidang pekerjaan tersebut akan tersendat atau akan menjadi berantakan.

Dan apabila suatu bidang pekerjaan yang yang sudah sesuai dengan bidangnya maka bidang pekerjaan tersebut hendaknya ditekuni dan bertekad dalam suatu bidang pekerjaan, sadar akan kewajibannya dalam menekuni bidang pekerjaannya yang dilakukan dan juga harus memiliki idealism yang tinggi untuk menejunjung tinggi suatu bidang pekerjaan karena sauatu profesi merupakan tidak hanya untuk mencari suatu nafkah akan tetapi pada diri sendiri yang telah bisa mencapai cita-cita yang diinginkan.

\section{E. Profesi Hukum}

Profesi hukum merupakan sebidang profesi yang berkatian dengan hukum dan yang melakukan profesi ini adalah orang-orang yang ahli dalam bidang hukum dan profesi ini merupakan hal penting dalam kehidupan dikarenakan profesi ini membantu, mengurangi dan serta memberikan arahan tentang hukum karena hukum merupakan arahan agar masyarakat taat hukum sehingga dapat menurunkan jumlah pelanggaran-pelanggaran ${ }^{12}$. Berbagai bidang tentang profesi hukum antara lain adalah :

1. Kepolisian

2. Kejaksaan

3. Kehakiman

4. Pengacara.

Perlu diketahui bahwa profesi hukum ini juga terdapat etikaetika yang harus dipatuhi dan merupakan acuan agar tidak terjadi pelanggaran yang tidak diinginkan dan atau yang disebut dengan kode etik untuk menghindari dari pada pelanggaran maka profesiprofesi hukum sendiri perlu adanya profesionalisme pada bidangnya masingmasing, profesionalisme sendiri ada karena setiap bidang-bidang profesi hukum menjadi pagar bagi instansi-intansi hukum atau yang bisa disebut dengan instansi publik dalam pelaksanan profesi hukum ada sumpah jabatan yang dimana sumpah tersebut sebagai ikrar agar terjadi suatu ikatan yang dimana dalam pelaksaan tugasnya terbentuk manusia-manusia yang profeisonal, loyalitas dan pelindung bagi masyarakat.

\section{F. Pelanggaran Profesi Hukum}

Setiap profesi hukum tidak luput dengan kesalahan dikarenakan setiap manusia pastinya tidaklah sempurna namun pelanggaranpelanggaran tetaplah pelanggaran maka harus diseleasikan sesuai aturan-aturan yang berlaku.Setiap profesi hukum pastinya ada wadah-wadah untuk mengatasi suatu permasalahan pelanggaran karena setiap profesi hukum ada aturan-aturan tertulis yang dimana mengatur dan bagaimana untuk mengatasi suatu masalah, dan konsekuensinya dari setiap pelanggaran harus di patuhi oleh pelanggar.

\footnotetext{
${ }^{12}$ Supriadi, Etika dan Tanggung Jawab Profesi Hukum Di Indonesia,, (Jakarta: Sinar Grafika, 2006), hal 19.
} 


\section{G. Kode Etik}

Kode etik menurut kamus bahasa Indonesia "kode" tanda yang disetujui untuk menyatakan maksud-maksud tertentu atau system dengan tanda-tanda rahasia untuk menjamin kerahasiaan pemerintah, berita dan sebagainya ${ }^{13}$. Sedangkan "etik" berkenaan dengan moral atau etika ${ }^{14}$. Sedangkan kode etik merupakan asas dan norma suatu kelompok tertentu sebagai landasan ukuran tingkah laku' ${ }^{15}$. Maka kode etik bisa di definiskan sekumpulan asas-asas atau norma-norma sebagai landasan yang tertulis untuk menyatakan maksud-maksud tertentu yang dimana sebagai pedoman dalam menjalankan suatu yang terlibat dalam bidang profesi hukum dan kode etik dibuat oleh sekelompok organisasi.

Kode etik profesi tidak sama dengan undang-undang hukum, seorang ahli profesi yang melanggar kode etik profesi menerima sanksi atau denda dari induk organisasinya sedangkan pelanggaran terhadap peraturan hukum (undang-undang) di hakimi/diadili oleh lembaga peradilan yang berwenang untuk itu, seperti pengadilan negeri, pengadilan agama, pengadilan tata usaha Negara dan badan vertikalnya ${ }^{16}$.

Dengan etika profesi hukum diharapkan professional hukum memepunyai kemampuan individu tertentu yang kritis, yaitu ${ }^{17}$ :

1. Kemampuan untuk kesadaran etis (ethical sesibility)

2. Kemampuan untuk berfikir secara etis (ethical reasoning)

3. Kemampuan untuk bertindak secara etis (ethical conduct)

4. Kemampuan untuk kepemimpinan secara etis (ethical leadership)

Dengan demikan kode etik merupakan jalan atau alur dalam kehidupan setiap profesi berjalannya sebuah profesi yang berkenaan dengan bermasyarakat yan penuh dengan kesadaran, berfikirdan berkepemimpinan yang etis karena berkenaan dengan itu semua sebuah profesi dalam berjalannya profesi akan tidak akan menyimpang dari sebuah kesalahan.

Selain undang-undang Advokat seorang Advokat juga mengacu kepada Kode Etik karena Kode Etik merupakan penjelasan bagaimana hak dan kewajiban seorang Advokat didalam pasal 26 ayat (1) undang-undang no 18 tahun 2003 tentang Advokat yang selanjutnya disingkat dengan uu no 18 tahun 2003 menyebutkan:

"Untuk menjaga martabat dan kehormatan profesi advokat, disusun kode etik profesi advokat oleh organisasi advokat”. Maka sesuai dengan pasal dan ayat di atas organisai yang memayungi advokat membuat sebuah aturan-aturan yang berkenaan dengan bagaimana dan seperti apa yang harus dilakukan oleh setiap anggota.dan undang-undang advokat dan kode etik advokat harus dipatuhi oleh anggota organisasi advokat.

\footnotetext{
${ }^{13}$ Peter Salim. Kamus Besar Bahasa Indonesia Kontemporer. Modern Englishpres. Jakarta. Edisi pertama. 1991. kode hal 751

${ }^{14}$ Ibid. etik hal 408

15 Ibid kode etik hal 751

${ }^{16}$ Sutrisno,.Etika Profesi HUkum. upnpress. Surabaya. 2011. hal 45

${ }^{17}$ Ibid hal 45
} 


\section{H. Larangan Dan Sanksi Advokat}

Larangan merupakan sesuatu yang tidak boleh dilakukan oleh siapapun jika pelanggaran dilakukan maka seseorang yang melakukan pelanggaran akan terkena sanksi atau hukuman.dan seorang advokat jika melakukan pelanggarang adaan dikenai sanksisaksi. Larangan bagi advokat antara lain adalah yang dimana tertuang pada pasal 3 huruf (c) UU no 18 tahun 2003 yang berbunyi: "tidak sebagai pegawai negeri dan pejabat Negara". Dimaksudkan pada pasal ini adalah seorang yang bekerja sebagai pegawai negeri tidak diperkenankan sebagai Advokat dan pejabat Negara tidak diperkenankan sebagai Advokat.Selain itu pada pasal 6 UU no 18 tahun 2003 menyebutkan alasan-alasan Advokat yang dikenai tindakan akan tetapi dengan alasan:

a. Mengabaikan atau menlantarkan Kliennya

b. Berbuat atau bertingkah laku yang tidak patut terhadap lawan atau rekan seprofesinya

c. Bersikap, bertingkah laku, atau mengeluarkan pernyataan yang menunjukan sikap tidak hormat terhadap hukum, peraturan perundang-undangan, atau pengadilan

d. Berbuat hal-hal yang bertentangan dengan kewajiban, kehormatan atau harkat dan martabat profesinya

e. Melakukan pelanggaran terhadap peraturan perunadngundangan dan atau perbuatan tercela

f. Melanggar sumpah/janji Advokat dan/atau kode etik advokat.

Dengan demikian jika seorang Advokat melanggar yang dimana sesuai dengan pasal 6 UU no 18 tahun 2003 maka setiap anggota Advokat yang melanggar akan dikenai sanksi yang dimana tertuang pada pasal 7 UU no 18 tahun 2003 yang dimana pada ayat (1) di jelaskan jenis tindakan yang akan dijatuhkan atau diberikan sanksi antara lain:

a. Teguran lisan

b. Terguran tertulis

c. Pemberhentian sementara dari profesinya selama 3 (tiga) bulan sampai 12 (dua belas) bulan

d. Pemberhentian tetap dari profesinya

Pada pasal 7 ayat (2) UU No. 18 tahun 2003 menjelaskan bahwa ketentuan dan jenis tingkatan perbuatan pelanggaran Advokat yang dimaksudkan pada ayat (1) diatur lebih lanjut oleh Dewan Kehormatan Organisasi Advokat. Pada pasal 7 ayat (3) menjelaskan bahwa yang dimana sesuai dengan ayat (1) setiap Advokat yang di berikan sanksi dapat melakukan pembelaan diri.

Dalam pelanggaran yang diberikan kepada Advokat tidak hanya mengacu pada UU no 18 tahun 2003 akan tetapi diatur pada Kode Etik Advokat yang dimana pada pasal 16 (1) Kode Etik Advokat yang diberikan oleh Organisasi kepada Advokat hampir sama dengan pasal 7 ayat (1) UU no 18 tahun 2003 yang dimana pada pasal 16 ayat (1) Kode Etik Advokat menyebutkan bahwa “(1) Hukuman yang diberikan dalam keputusan dapat berupa:

1. Peringatan biasa 
Logika : Journal of Multidisciplinary Studies, ISSN 2085-9970.

Vol. 10 Nomor 01 Juni 2019. 40-50.

2. Peringatan keras

3. Pemberhentian sementara untuk waktu tertentu

4. Pemecatan dari keanggotaan Organisasi profesi

Pada ayat (2) pasal 16 Kode Etik Advokat menjelaskan tentang pertimbangan bagaimana sanksi yang akan diberikan dengan sifat berat atau ringannya suatu pelanggaran.

Pada ayat (3) pasal 16 Kode Etik Advokat menjelaskan jika seorang Advoakt yang diberikan sanksi pemberhentian sementara waktu maka Advokat tersebut dilarang menjalankan profesinya baik dalam maupun luar pengadilan. Pada ayat (4) pasal 16 Kode Etik Advokat menjelaskan apabila seorang Advokat yang diberhentikan sementara maupun dipecat dari keanggotaan maka Organisasi Advokat menyampaikan kepada Mahkamah Agung untuk diketahui dan dicatat dalam dafter anggota dimaksudkan bahwa Advokat tersebut sudah dipecat atau di berhentikan sementara waktu.

\section{Studi Kasus (Pelanggaran Kode Etik Advokat Dalam Pembuatan Surat Kuasa)}

Beragam cara melanggar kode etik Advokat untuk memberikan keuntungan pada salah satu pihak membuat berbagai hal yang seharusnya tidak boleh dilakukan menjadi pilihan utama, Memanipulasi Surat Kuasa seringkali terjadi pada beberapa kasus seperti halnya kasus Edi Susilo yang menderita lumpuh dan meminta Advokat untuk menangani masalahnya tentang sengketa perdata di Temanggung pada tahun 2013 kala itu. Pihak Advokat nekat memalsukan surat kuasa demi mendapatkan untung melimpah dari Edi. Manipulasi Surat Kuasa mulai dari hal yang terkecil memalsukan tanda tangan misalnya hingga membuat surat kuasa penuh atas kemauan pribadi. Pada praktiknya dalam studi lapangan tidak sedikit yang melakukan hal tersebut untuk berbagai bentuk kepentingan individual maupun secara komersial.Dalam wawancara saya dengan mantan kepala PKPA di salah satu perguruan tinggi di Jawa Tengah, berbagai hal unik kami dapatkan melalui instrumen observasi wawancara dengan bapak tersebut.

"Banyak kasus-kasus manipulasi surat kuasa hanya untuk mendapatkan kemenangan yang seharusnya bukan porsinya untuk menang, hal ini seharusnya tidak terjadi di dalam Advokat, karena Advokat merupakan profesi mulia dan amat berat tanggungannya tidak hanya di dunia jika salah, tapi di akhirat akan jauh lebih parah".

Pada esensinya profesi Advokat merupakan bentuk penegakkan hukum yang membantu masyarakat dalam menyelesaikan masalah sesuai dengan porsi dan yang seharusnya diterima oleh klien tersebut, bukan untuk memenangkan atau memperjuangkan orang yang menghadapi masalah hukum. Untuk itu dalam profesi Advokat tidak dibenarkan memberikan jaminan penuh untuk memenangkan kliennya seperti halnya pada pasal yang telah diatur dalam UU Advokat No. 18 tahun 2003 ayat 4 "Advokat tidak dibenarkan menjamin kepada kliennya bahwa perkara yang ditanganinya akan menang”. Dengan demikian jelas bahwa Advokat mempunyai sifat mendampingi dan membantu sesuai dengan kemampuannya.Namun sayangnya dalam praktik riilnya banyak kasus-kasus yang melanggar kode etik tersebut. Bukan hanya banyak pihak yang dirugikan akan tetapi esensi utuh profesi Advokat seakan sirna termakan nafsu individualis. 
Mantan kepala PKPA tersebut juga menuturkan bahwa esensi dari Advokat bukanlah tentang pembelaan akan tetapi tentang penempatan porsi hukum yang sesuai dengan apa yang klien alami.

"Lawyer itu bukanlah pekerjaan yang mudah, Lawyer merupakan profesi tidak semua orang bisa menjadi Lawyer, bayangkan saja ketika akan lulus dan menjadi Lawyer, dia akan disumpah dulu untuk mendapatkan gelar dan profesi yang akan ia jalani sebagai Lawyer. Bukan hanya itu, Seorang Lawyer sejati harus menerima Klien walau dalam keadaan apapun, miskin, kaya, pejabat, koruptor sekalipun harus diterima, karena apa? Karena Lawyer hanya mempunyai sifat mengantarkan saja kepada porsi hukum yang sesuai dengan yang harus ia terima, dalam tanda kutip bukan pembelaan, melainkan menempatkan ke porsi hukum yang sesuai dengan perbuatannya. Akan tetapi, kami juga berhak menentukan siapa yang pantas kita bantu dan itu juga ada patokan-patokan tersendiri, ketika ada klien yang meminta bantuan, kami akan siap membantu akan tetapi jika porsi kemenangannya sedikit atau bisa dikatakan cenderung akan kalah kami akan melimpahkannya kepada lawyer yang lain dan memberikan keterangan kepada klien bahwa kami sudah bersedia sekuat tenaga akan tetapi kemungkinan besar jika saya bantu klien akan gagal”

\section{SIMPULAN}

Advokat adalah orang yang berpraktek memberi jasa hukum, baik didalam maupun diluar pengadilan yang memenuhi persyaratan berdasarkan undang-undang yang berlaku, baik sebagai Advokat, Pengacara, Penasehat Hukum, Pengacara praktek ataupun sebagai konsultan hukum.

Apabila seorang advokat yang dimana telah melanggar dan faktor-faktor apa sajakah yang yang membuat seorang dapat terkena sanksi dari dewan kehormatan, jika terbukti melakukan pelanggaran Kode Etik Advokat seorang advokat dapat dijerat atau di sanksi baik dari perundangan KUHP yang dimana mengatur tentang tindak pidana serta KUHP perdata yang mengatur keperdataan dan serta dapat pula dikenakan sanksi dari organisasi advokat yang ada dalam hal ini semua dapat aturan yang berlaku seorang advokat wajib menjalankan dan sesuai bagaimana pelaporan seorang klien agar terjadi bagaiman seorang advokat dapat memepertanggung jawabkannya. Maka dari itu setiap organisasi memberikan sanksi tegas bilamana seorang avokat telah melakukan pelanggaran Kode Etik Advokat.

\section{SARAN}

Pelanggaran kode etik advokat dapat di minimalisir atau dapat dicegah beberapa diantaranya dengan menegakkan kode etik advokat penegakan kode etik diartikan sebagai kemampuan komunitas advokat dan organisasinya untuk memaksakan kepatuhan atas ketentuan-ketentuan etika bagi para anggotanya, memproses dugaan terjadi pelanggaran kode etik dan menindak anggota yang melanggar ketentuan-ketentuan yang tercantum didalamnya.

Untuk tetap mempertahankan kualitas para anggotanya, sebuah organisasi advokat harus memperhatikan kompetensi intelektual para anggotanya agar lebih baik lagi mutu pelayanannya kepada masyarakat. 
Logika : Journal of Multidisciplinary Studies, ISSN 2085-9970.

Vol. 10 Nomor 01 Juni 2019. 40-50.

\section{DAFTAR PUSTAKA}

Abdurahman, Aspek-aspek Bantuan Hukum di Indonesia, Cendana Press, Jakarta,1983

Bertens K. Etika. PT. Gramedia Pustaka Utama. Jakarta. 2002.

Binziad Kadafi, dkk, Advokat Indonesia mencari legitimasi study tentang tanggung jawab profesi hukum di Indonesia, Pusat Studi Hukum dan Kebijakan Indonesia, Jakarta,2002

Peter, Salim. Kamus Besar Bahasa Indonesia Kontemporer. Modern Englishpres. Jakarta. Edisi Pertama 1991.

Soerjono Soekanto, Bantuan Hukum Suatu tinjauan Sosio-Yuridis, Ghalia Indah, Jakarta, 1983

Soerjono Soekanto, Penegakan Hukum. cet. 2007, BPHN7 Binacipta, Jakarta,1983

Sutrisno. Etika Profesi Hukum. upnpress. Surabaya. 2011.

Valerie Miller dan Jane Copey, Pedoman Advokasi: Kerangka kerja Untuk Perencanaan, Tindakan dan Refleksi, Yayasan Obor Indonesia, Jakarta, 2005.

Yulianingsih, Wiwin. Etika Profesi Hukum. upnpress. Surabaya. 2011.

Todung Mulya Lubis, ,Bantuan Hukum dan Kemiskinan Struktural, Jakarta: Cendana Press, 1983

Yahya Harahap, Pembahasan dan Penerapan KUHAP: Penyidikan dan Penuntutan, Sinar Grafika, Jakarta,2009.

PERATURAN PERUNDANG-UNDANGAN

Undang-Undang Dasar NRI Tahun 1945

Kitab Undang-Undang Hukum Pidana

Kitab Undang-Undang Hukum Acara Pidana

Undang-Undang Nomor 18 Tahun 2003 tentang Advokat

Undang-Undang Nomor 16 Tahun 2011 tentang Bantuan Hukum 